\title{
Effects of mushroom (Lentinula edodes) extract on growth performance, immune response and hemato-biochemical parameters of great sturgeon juvenile (Huso huso Linnaeus, 1754)
}

\author{
H Chitsaz*, R Akrami, Z Ahmadi \\ Department of Fisheries, Azadshahr Branch, Islamic Azad University, Azadshahr, Iran
}

Received: February 2018

Accepted: April 2018

\begin{abstract}
This research was carried out to survey the ffects of dietary of Lentinula edodes mushroom extract as a feed supplement on growth performance and survival rate, immune response, hematological and biochemical characteristics of beluga juvenile (Huso huso). Four hundred and fifty fish after acclimation with average weight of $40.45 \pm 5.72 \mathrm{~g}$ were fed in a wholly randomized design in 5 treatments (basic diet containing 0\% (control), $00.5 \%, 1 \%$, $1.5 \%$ and $2 \%$ L. edodes mushroom extract) and 3 replicates. During the experiment (56 days), a total of eight samples were taken in 8 weeks. The mean of data were analyzed using oneway ANOVA and Duncan's post hoc test at 5\% level. Results indicated that administration of $2 \%$ of mushroom extract for 8 weeks improved weight gain, specific growth rate and feed conversion ratio of beluga $(\mathrm{P}<0.05)$.
\end{abstract}

Correspondence: $\mathrm{H}$ Chitsaz, Department of Fisheries, Azadshahr Branch, Islamic Azad University, Azadshahr, Iran (e-mail: chitsaz2@gmail.com).
Among the investigated hematological indices, Supplementing $2 \%$ L. edodes resulted in increased levels of the erythrocytes (RBC), hemoglobin $(\mathrm{Hb})$, haematocrit (Hct) in comparison with the control group $(\mathrm{P}<0.05)$. At the end of the assay, there were significant decreased in some of the biochemical parameters (Cholesterol, alkaline phosphatase (ALP) and alanine aminotransferase (ALT)) in the treatments containing mashroom extract $(\mathrm{P}$ $<0.05)$. Also the activity of serum lysozyme activity and superoxide dismutase (SOD) Among immune parameters studied were increased in group of $2 \%$ of $L$. edodes compared to other treatments $(\mathrm{P}<0.05)$. These results indicated that the addition of supplemental mashroom extracts, especially at $2 \%$ level to the beluga juveniles diet, were improved the growth performance, some hematological and biochemical parameters and immune response of beluga juvenile.

Keywords: Hemato - Immunological parameters, growth, Huso huso, Lentinula edodes (mushroom) extract. 


\section{Introduction}

One of the most valuable fish species in the Caspian Sea is The beluga (H. huso) which is known as the largest species among caviar fish (Jalali, Hosseini, \& Imanpour 2008).Great Sturgeon has special features such as rapid growth, market price, easy reproduction and high endurance against adverse environmental conditions, which makes it an appropriate species in the aquaculture industry (Mohseni, Ozorio, Pourkazemi, \& Bai 2008; Abtahi, Yousefi, \& Kenari 2013). The rearing of sturgeon has seen considerable advances in past years (Amlashi, Falahatkar, Sattari, \& Gilani 2011). So, further reconnaissance of commercially available dietary additives to ameliorate performance and disease resistance of these fish is still highly demanded. Bans and restrictions of antibiotics as edible additives in fish breeding in many countries have resulted in the enhancement in studies on alternative dietary supplements such as medicinal herbs to augment the health and production of cultured fish. Phytogenics can exert multiple effects on organisms, including the betterment of feed palatability, efficiency and digestion, decrease of nitrogen excretion and improvement of intestine flora and health status (Harikrishnan, Balasundaram, \& Heo 2011; Sheikhzadeh, Nofouzi, Delazar, \& Oushani 2011). Meanwhile, other virtues of herbs, such as antioxidant and antiviral properties, or their effects on the immune system cannot be ignored. One such instance is Lentinula edodes mushroom extract. Fungus have been used as food for centuries all over the world due to their characteristic soft contexture and mild flavor (Wandati, Kenji, \& Onguso 2013). They are documented as being good source of nutrients and bioactive compounds which are useful to the human body (Chang \& Miles 2011). pharmaceutical mushroom, L. edodes, an edible fungus, that is also known as Shiitake mushroom was chosen for the present study. This mushroom has been attributed with many medical properties both in eastern and western medicine. On human health, the effects could range from diminish cholesterol, lowering blood pressure, reinforcement the immune system against diseases, containing viral ones, fighting tumors, and improving liver function (Bobek, Ginter, Kuniak, Babala, Jurcovicova, Ozdin \& Cerven 1991; Mau, Lin, \& Song 2002; Reguła \& Siwulski 2007). This function of mushroom extract is due to compounds such as saponins, terpenoids, polyphenols and flavonoids (Wandati et al. 2013). Saponins have been reported to possess a vast range of pharmacological properties, including antiinflammatory and anti-diabetic properties (Lee et al. 2012). Terpenoids (isoprenoids) are secondary metabolites with molecular structures containing carbon backbones made up of isoprene (Wandati et al. 2013). The compounds have been expressed to show a intensive range of pharmacological benefits that embrace anti-malarial, anti-inflammatory and anti-cancer among others (Thoppil \& Bishayee 2011). Phenolic compound are antioxidant and exhibit a vast extensive of spectrum medicinal attributes (Mariappan, 
Vinayagam, \& Durai 2015). The total polyphenols content show a positive correlation with flavonoids (Nijveldt, Van Nood, Van Hoorn, Boelens, Van Norren \&Van Leeuwen 2001). Polyphenols from various natural sources has plants (Alberto, Rinsdahl, Canavosio, \& Manca de Nadra 2006), have been reported to have a variety of biological effects, among antimicrobial activities. Flavonoids are synthesized by plants as a response to microbial infections and are recognized to have effective antimicrobial effects against a vast range of microorganisms (Recio, Rios, \& Villar 1989). The mushrooms could improve health because of its chemical compounds which are: lentinan, eritadenine, and Lergothioneine (Smith, Rowan, \& Sullivan 2002; Bernaś, Jaworska, \& Lisiewska 2006). In addition the Shiitake mushroom has several anti-oxidants (selenium, uric acid, vitamin $\mathrm{A}, \mathrm{E}, \mathrm{C}$ ) as well as vitamin D (Mau et al. 2002).

Several investigations have confirmed the positive effects of medicinal plants on great sturgeon (Binaii, Ghiasi, Farabi, Pourgholam, Fazli, Safari, Alavi, Taghavi, \& Bankehsaz 2014; Gholipour Kanani, Nobahar, Kakoolaki, \& Jafarian 2014; Akrami, Gharaei, Mansour \& Galeshi 2015; Vahedi, Hasanpour, Akrami, \& Chitsaz 2017), but there is no valid evidence based on the affect of mushroom extract on growth performance, innate immune response and hemato-biochemical parameters of beluga juvenile. Hence, the target of the current research evaluated effects of dietary supplementation of L. edodes mushroom extract on the immune response, growth performance and hematobiochemical parameters of great sturgeon juvenile (H. huso) in the natural environmental conditions of a commercial farm.

\section{Materials and Methods}

\section{Fish}

450 Juvenile sturgeon (H. huso) weighing 40.45 $\pm 5.72 \mathrm{~g}$ were obtained from Sadd-e Voshmgir Fisheries complex (Golestan province,next to Caspian sea, Iran) and used for the experiments. The health status of fish was inspectedand observed immediately upon arrival in the ponds and with 14 day intervals there after based on standardized laboratory procedures (Austin \& Austin 1989). The fish did not show any signs of disease during the acclimation period. Fish were randomly distributed into 5 groups following a totall randomized design, with each group consisting of 30 fish. These groups were triplicate utilizing the same design. Prior to the trials the fish were adapted to the conditions in the test ponds. Before the experiment was initiated, the fish were fed commercial sturgeon feed pellets for 8 weeks. The trials were carried out in 15 polypropylene tanks [30 fish per tank $(2 \mathrm{~m} \times 2 \mathrm{~m} \times 0.5 \mathrm{~m})]$ with the flow rate set at 1.5 litres $\mathrm{s}^{-1}$, water temperature $18-21^{\circ} \mathrm{C}$ and dissolved oxygen 6-8 ppm for 56 days. Adaptation to these tanks was performed for 10 days with a commercially pelleted diet from Faradaneh company products used for sturgeon $3-5 \%$ of the body weight twice per day during the acclimation period.

\section{Preparation of L. edodes mushroom extract}


L. edodes was collected from a local market and the production process of $L$. edodes mushroom extracted in water was done according to the method described by (Yap \& $\mathrm{Ng} 2001$ ) and can be summarized by the following steps: $500 \mathrm{~g}$ of mushroom were dissolved in $1000 \mathrm{~mL}$ of water in glass thermos. The thermos were firmly covered with aluminium foil and kept for $24 \mathrm{~h}$ in $60-65{ }^{\circ} \mathrm{C}$ temperature of water bath. Mushroom extract was filtered through filter paper to remove particles. The final solution was lyophilized in dark bottles and kept at $4{ }^{\circ} \mathrm{C}$. For the trials, $0.5 \%, 1 \%, 1.5 \%$ and $2 \%$ concentrations of the lyophilized mushroom extract were added to the commercial sturgeon feed and then stored in the fridge until use.

\section{Diet preparation}

To prepare the diets, a commercial pellet diet (containing $48-50 \%$ protein, $12-16 \%$ lipid and $7-10 \%$ ash) for sturgeon fishes. This diet without mashroom extract was considered as control diet. The experimental diet was prepared utilizing the basal diet supplemented with $0.5 \%, 1 \%, 1.5 \%$ and $2 \%$ L. edodes mushroom extract. To prepare the diets, a commercial pellet diet was blended, then combined with the mushroom extract with water ( $100 \mathrm{~mL}$ of water $/ \mathrm{kg}$ of diet) to form a paste, which passed through a meat grinder and were allowed to dry for $18 \mathrm{~h}$ at $45^{\circ} \mathrm{C}$ by air circulation and stored at $4^{\circ} \mathrm{C}$ until use (Razaghi Mansour, Akrami, Ghobadi, Denji, Ezatrahimi \& Gharaei 2012; Akrami, Iri, Rostami, \& Razaghi Mansour 2013). Juveniles were fed the experimental diet for 8 weeks in rate of 3-5 percen of the body weight per day, spread across two feeding times (07:00 and 19:00).

\section{Growth performance}

To regulate the feeding amount and estimate growth performance, all of fish from each tank were biometried and weighted every 15 days during the experiment, at least $24 \mathrm{~h}$ after the last feeding. At the end of the feeding trial, weight gain (WG\%), specific growth rate (SGR; \% $\mathrm{ady}^{-1}$ ) and feed conversion ratio (FCR) were calculated based on the following formulas:

$\mathrm{WG}(\%)=100 \times(\mathrm{Wt}-\mathrm{W} 0) \times 100 / \mathrm{W} 0($ Tacon 1990).

$\mathrm{FCR}=$ dry feed intake $(\mathrm{g}) /$ wet WG $(\mathrm{g})$ (Hevrøy, Espe, Waagbø, Sandnes, Ruud \& Hemri 2005).

SGR $\left(\%\right.$ day $\left.^{-1}\right)=\left(\operatorname{Ln~} \mathrm{W}_{\mathrm{t}}-\mathrm{Ln} \mathrm{W}_{0}\right) \times 100 / \mathrm{t}$ (Hevrøy et al. 2005).

Survival rate $=\left(\mathrm{N}_{\mathrm{t}} / \mathrm{N}_{0}\right) \times 100(\mathrm{Ai}$, Mai, Tan, Xu, Duan, Ma, \& Zhang 2006).

Here, $\mathrm{W}_{\mathrm{t}}$ and $\mathrm{W}_{0}$ are final and initial body weights $(\mathrm{g})$, respectively, $\mathrm{t}$ is duration of experimental days, $\mathrm{N}_{0}$ is the initial number of fish, and $\mathrm{N}_{\mathrm{t}}$ is the final number of fish.

\section{Blood sample collection and serum separation}

At the end of trial, ten fish catch from each tank were sampled for blood. In order to provide sufficient blood for the subsequent assays fish were anesthetized by using clove oil (Eugina caryophillata), then by use of a syringe, $4 \mathrm{ml}$ 
blood samples removed from the caudal vein. For serum isolation, blood samples were put into non-heparinized tubes and left to clot for $12 \mathrm{~h}\left(\right.$ at $\left.4{ }^{\circ} \mathrm{C}\right)$, prior to centrifugation at $5000 \mathrm{~g}$ for $5 \mathrm{~min}$ in a clinical centrifuge. Isolated sera were stored at $-20{ }^{\circ} \mathrm{C}$ until further analysis (Soleimani, Hoseinifar, Merrifield, Barati, \& Abadi 2012).

\section{Hematological levels}

In order to study the hematological parameters, the blood samples were suspended in heparinized tube made from the blood of 10 fish in each group. To measure blood parameters, the following were performed:

1-Values of red blood cell (RBC) and white blood cell (WBC) counts were determined using a Neubaeur hemocytometer based on method of (Martins, Tavares-Dias, Fujimoto, Onaka, \& Nomura 2004).

2-Hemoglobin levels $(\mathrm{Hb})$ were determined by the cyano-methemoglobin spectrophotometry method (Biochorm Libra S12, UK).

3- Hematocrit level were determined by method of (Schaperclaus, Kulow \& Schreckenbach 1991). In this method Blood samples of fish were taken into heparinized capillary tubes. Duplicate samples were used from each fish. The tubes were then centrifuged (at $10.500 \mathrm{~g}$ for $5 \mathrm{~min}$ ) in a hematocrit centrifuge. The percentage hematocrit value was measured by overlaying the tubes on a sliding scale hematocrit reader.

4- Differential leukocyte counts (monocyte, lymphocyte and neutrophil) was made in peripheral blood smears stained with MayGrunwald and Giemsa stains (Ghiasi, Mirzargar, Badakhshan, \& Shamsi 2010).

\section{Biochemical assays}

Blood biochemical parameters were evaluated based on the following laboratory methods utilizing an auto - analyzer BT - 3000 (Biotecnica, Italy) and commercial kits (Pars azmoon, Tehran, Iran). Total protein and glucose levels (glucose oxidase) were measured by the Biuret and glucose oxidase methods, respectively (Asadi, Hallajian, Asadian, Shahriari, \& Pourkabir 2009). Triglycerides were obtained lipase (lipase / GPO - PAP), cholesterol (cholesterol oxidase), albumin (Bromocresol Green method) (Borges, Scotti, Siqueira, Jurinitz, \& Wassermann 2004). Globulin was calculated by subtracting albumin value from total plasma protein (Maqsood, Samoon, \& Singh 2009) Aspartate aminotransferase (AST), alanine aminotransferase (ALT) and lactate dehydrogenase (LDH) enzymes were distinguished by colorimetrically and alkaline phosphatase (ALP) was determined using an enzymatic method (Borges et al. 2004).

\section{Immune parameters assay}

\section{Lysozyme activity}

The Lysozyme level in blood was determined by using a modified lysoplate base on the method described by (Siwicki, Anderson 1993) with slight. Modifications. Briefly, aliquots 2 $\mathrm{ml}$ of Micrococcus lysodeikticus suspension (Sigma, USA) (0.375 mg ml-1, $0.05 \mathrm{M}$ sodium phosphate buffer, $\mathrm{pH}$ 6.2) and $50 \mu \mathrm{l}$ of each 
serum sample were mixed properly for $15 \mathrm{~s}$ and measured in a spectrophotometer at $450 \mathrm{~nm}$ (Biochorm Libra S12, UK). The optical density was immediately measured at intervals of 15,30 and $270 \mathrm{~s}$. A unit of lysozyme activity was defined as the amount of sample causing a reduction in absorbance of $0.001 \mathrm{~min}^{-1}$ and lysozyme activity was expressed as units $(\mathrm{U})$ per minute.

\section{Determination of serum Ig level}

Procedure wherein the immunoglobulin is first precipitated out of solution with polyethylene glycol $(10.000 \mathrm{kDa})$.for this assay, $100 \mu \mathrm{l}$ of the plasma were mixed with an equal amount of $12 \%$ polyethylene glycol and in incubated for $2 \mathrm{~h}$ under constant agitation at room temperature. After centrifugation at $5000 \times \mathrm{g}$ for $15 \mathrm{~min}$, the supernatant was removed and the remaining concentration of protein determined by subtracting this figure from the total serum protein concentration (Siwicki, Anderson 1993).

\section{Serum superoxide dismutase (SOD) activity}

The activity of superoxide dismutase (SOD) was determined by RANSOD kit (RANdox Labratories Ltd. UK). Briefly, At first was collected beluga blood using EDTA as anticoagulant. In this method, xanthine and xanthine oxidase were used, and the radicals were able to react with 2- (4 - idophenyl) - 3 - (4 - nitrophenol) - 5 - phenyltrazolium chloride (INT) and produce a formazan red, measured at $505 \mathrm{~nm}$ (Biochorm Libra S12, UK). Due to existed of the enzyme SOD in the sample, the superoxide radicals was turned into hydrogen peroxide and oxygen and prevented the formation of red formazan. Activity was determined by the degree of prevention of this reaction. For measurment SOD: a $50 \mathrm{ml}$ of RBC and disilled water $\left(1: 200 \mathrm{v} \mathrm{v}^{-1}\right.$, equivalent to approx $75 \mathrm{mg} \mathrm{Hb}$ ) was utilized. Enzyme activity was computed as (U SOD / $\mathrm{g} \mathrm{Hb}$ ).

\section{Alternative complement activity (ACH50)}

Alternative complement activity was tased based on the procedure of (Ortuño, Cuesta, Rodríguez, Esteban, \& Meseguer 2002). In this method $(500 \mu 1)$ of test serum as complement source, serially diluted in Hank's buffer (HBSS), were added to $500 \mu 1$ of SRBC (final concentrations $10-0.078 \%$ ). Then put samples in incubator at $22^{\circ} \mathrm{C}$ for 1 hour and were centrifuged $800 \times \mathrm{g}$ for $5 \mathrm{~min}$ at $4^{\circ} \mathrm{C}$ to remove non-lysed RBC. The relative hemoglobin content of the supernatants was assessed by measuring their optical density at $540 \mathrm{~nm}$ in a spectrophotometer (Biochorm Libra S12, UK). The values of maximum (100\%) and minimum (spontaneous) hemolysis were obtained by adding 5001 of distilled water or HBSS to 500 1 samples of SRBC, respectively. The degree of haemolysis (Y) was estimated and the lysis curve for each specimen was obtained by plotting Y / (1-Y) against the volume of serum added (ml) on a $\log -\log$ scaled graph. The volume of serum producing $50 \%$ haemolysis (ACH50) was determined and the number of ACH50 units $\mathrm{ml}^{-1}$ was obtained for each experimental group.

\section{Respiratory burst activity}

Respiratory burst activity of neutrophils was quantified utilizing the reduction of nitroblue 
tetrazolium (NBT) to formazon as a measure of superoxide anion $\left(\mathrm{O}_{2}^{-}\right)$production. This test was done by the method of (Secombes 1990) as modified by (Stasiack \& Bauman 1996).The blood was collected by piercing the caudal peduncle in a test tube containing 2.7\% EDTA as anticoagulant. Fifty microlitres of blood was placed into the wells of ' $U$ ' bottom microtitre plates and incubated at $37^{\circ} \mathrm{C}$ for $1 \mathrm{~h}$ to facilitate adhesion of cells. Then the supernatant was removed and the adhered wells were washed three times in PBS. In this step, $50 \mathrm{ml}$ of $0.2 \%$ NBT was added and resulting solution was incubated for a further hour. The cells were then fixed with $100 \%$ methanol for 2-3 min and again washed thrice with $30 \%$ methanol. The plates were then air dried. Sixty microlitres $2 \mathrm{~N}$ potassium hydroxide and $70 \mathrm{ml}$ dimethyl sulphoxide were added into per well to dissolve the formazon blue precipitate formed. The OD of the turquoise blue solution was then read in an ELISA reader at $540 \mathrm{~nm}$ (Elisa Reader, SCO GmbH Reader MPR1, Germany).

\section{Statistical analysis}

Values were expressed as Mean \pm standard diviation (SD). The immune response, stress resistance, digestive enzyme activities and growth performance were tested using one-way ANOVA and Duncan's multiple range test was used for comparison of the average values at the $5 \%$ level of significance utilizig software SPSS (Version 16.0).

\section{Results}

\section{growth performance}

The growth performance of great surgeon fed diets supplemented with varying levels of dietary L. edodes mushroom extract is presented in Table 1. Compared to the control treatment, fishes fed $2.0 \mathrm{~g} \mathrm{~L}$. edodes mushroom extract $\mathrm{kg}^{-}$ 1 diet displayed improved $(\mathrm{P}<0.05)$ growth performance, containing weight gain $\left(\mathrm{g} \mathrm{kg}^{-1}\right)$, SGR and FCR. There were no remarkable differences in survival rate among experimental and control $(\mathrm{P}>0.05)$.

Table 1. Growth performance and feed utilization of great sturgeon juvenile fed with diets containing different levels of L. edodes for 8 weeks.

\begin{tabular}{llllll}
\hline Parameters & Control & $\mathbf{0 . 5}$ & $\mathbf{1}$ & $\mathbf{1 . 5}$ & $\mathbf{2}$ \\
\hline Weight gain $\%$ & $618.3 \pm 23.9^{\mathrm{c}}$ & $632.4 \pm 35.3^{\mathrm{c}}$ & $662.23 \pm 46.2^{\mathrm{b}}$ & $689.2 \pm 39.1^{\mathrm{b}}$ & $748.1 \pm 52.9^{\mathrm{a}}$ \\
SGR (\%/day) & $3.43 \pm 0.11^{\mathrm{b}}$ & $3.81 \pm 0.31^{\mathrm{b}}$ & $3.95 \pm 0.20^{\mathrm{ab}}$ & $4.00 \pm 0.16^{\mathrm{ab}}$ & $4.11 \pm 0.22^{\mathrm{a}}$ \\
FCR & $0.98 \pm 0.04^{\mathrm{a}}$ & $0.91 \pm 0.07^{\mathrm{b}}$ & $0.89 \pm 0.05^{\mathrm{b}}$ & $0.82 \pm 0.02^{\mathrm{b}}$ & $0.75 \pm 0.16^{\mathrm{c}}$ \\
Survival (\%) & $100^{\mathrm{a}}$ & $100^{\mathrm{a}}$ & $100^{\mathrm{a}}$ & $100^{\mathrm{a}}$ & $100^{\mathrm{a}}$ \\
\hline $\begin{array}{l}\text { Data expressed as mean } \\
\text { different }(\mathrm{P}>0.05) .\end{array}$
\end{tabular}

\section{Biochemical assays}

\section{Biochemical analysis was carried out in following} sequence

The results of blood serum biochemical test of great sturgeon juveniles fed with $L$. edodes mushroom such as Cholestrol, ALT, ALP, Triglycerid, Glucose, Total Lipid,Total protein, 
Albumin, Globulin, LDH and AST are given in

Table 2. The lowest Cholestrol and the highest ALT and ALP levels was observed in $2 \%$ L. edodes extract group, which was differ significantly from control group $(\mathrm{P}<0.05)$. Glucose, Triglycerid, Total Lipid, Total protein, Albumin, Globulin,
LDH and AST activities among the various group of beluga fed L. edodes mushroom extract showed no significant differences $(\mathrm{P}>0.05)$. It can be observed that in mostly the best results were obtained in treatment containing $2 \% \mathrm{~L}$. edodes extract supplemented diet.

Table 2. Blood serum biochemical parameters of beluga juveniles fed with L. edodes mushroom (\% feed) added diet at different levels for 8 weeks

\begin{tabular}{llllll}
\hline parameter & Control & $\mathbf{0 . 5 \%}$ & $\mathbf{1 \%}$ & $\mathbf{1 . 5 \%}$ & $\mathbf{2 \%}$ \\
\hline Glucose $\left(\mathrm{mg} \mathrm{l}^{-1}\right)$ & $64.00 \pm 2.10^{\mathrm{a}}$ & $63.12 \pm 4.03^{\mathrm{a}}$ & $61.00 \pm 3.14^{\mathrm{a}}$ & $60.21 \pm 3.09^{\mathrm{a}}$ & $59.30 \pm 5.00^{\mathrm{a}}$ \\
Total Protein $\left(\mathrm{mg} \mathrm{l}^{-1}\right)$ & $1.28 \pm 0.09^{\mathrm{a}}$ & $1.75 \pm 0.47^{\mathrm{ab}}$ & $1.24 \pm 0.19^{\mathrm{a}}$ & $1.75 \pm 0.21^{\mathrm{a}}$ & $1.11 \pm 0.09^{\mathrm{a}}$ \\
Cholestrol $\left(\mathrm{mg} \mathrm{dl}^{-1}\right)$ & $98.6 \pm 17.22^{\mathrm{a}}$ & $85.12 \pm 13.10^{\mathrm{b}}$ & $81.19 \pm 13.02^{\mathrm{c}}$ & $65.47 \pm 11.12^{\mathrm{d}}$ & $45.36 \pm 9.24^{\mathrm{e}}$ \\
Albumin $\left(\mathrm{mg} \mathrm{l}^{-1}\right)$ & $0.56 \pm 0.12^{\mathrm{a}}$ & $0.53 \pm 0.31^{\mathrm{a}}$ & $0.49 \pm 0.15^{\mathrm{a}}$ & $0.60 \pm 0.24^{\mathrm{a}}$ & $0.59 \pm 0.25^{\mathrm{a}}$ \\
Globulin $\left(\mathrm{mg} \mathrm{l}^{-1}\right)$ & $0.53 \pm 0.01^{\mathrm{a}}$ & $0.6 \pm 0.11^{\mathrm{a}}$ & $0.63 \pm 0.05^{\mathrm{a}}$ & $0.68 \pm 0.09^{\mathrm{a}}$ & $0.54 \pm 0.08^{\mathrm{a}}$ \\
AST $\left(\mathrm{IU} \mathrm{dl}{ }^{-1}\right)$ & $440.65 \pm 55.20^{\mathrm{a}}$ & $442.66 \pm 51.67^{\mathrm{a}}$ & $446.83 \pm 43.84^{\mathrm{a}}$ & $449.32 \pm 45.20^{\mathrm{a}}$ & $450.40 \pm 48.18^{\mathrm{a}}$ \\
ALT $\left(\mathrm{IU} \mathrm{dl}{ }^{-1}\right)$ & $45.16 \pm 2.9^{\mathrm{a}}$ & $44.86 \pm 3.3^{\mathrm{a}}$ & $42.68 \pm 3.1^{\mathrm{a}}$ & $44.27 \pm 3.7^{\mathrm{a}}$ & $37.09 \pm 3.6^{\mathrm{b}}$ \\
ALP $\left.(\mathrm{IU} \mathrm{dl})^{-1}\right)$ & $568.20 \pm 45.60^{\mathrm{a}}$ & $581.50 \pm 52.36^{\mathrm{a}}$ & $584.74 \pm 45.19^{\mathrm{a}}$ & $571.20 \pm 59.12^{\mathrm{a}}$ & $542.50 \pm 65.20^{\mathrm{b}}$ \\
LDH $\left(\mathrm{IU} \mathrm{dl}^{-1}\right)$ & $587.23 \pm 44.11^{\mathrm{a}}$ & $570.50 \pm 34.17^{\mathrm{a}}$ & $581.80 \pm 42.21^{\mathrm{a}}$ & $575.19 \pm 39.11^{\mathrm{a}}$ & $590.11 \pm 45.64^{\mathrm{a}}$ \\
Triglycerid $\left(\mathrm{mg} \mathrm{dl}^{-1}\right)$ & $483.13 \pm 31.18^{\mathrm{a}}$ & $485.23 \pm 39.11^{\mathrm{a}}$ & $480.11 \pm 25.17^{\mathrm{a}}$ & $475.15 \pm 26.20^{\mathrm{a}}$ & $470.25 \pm 26.09^{\mathrm{a}}$ \\
Total Lipid $\left(\mathrm{mg} \mathrm{dl}^{-1}\right)$ & $415.14 \pm 27.23^{\mathrm{a}}$ & $398.45 \pm 23.25^{\mathrm{a}}$ & $401.84 \pm 25.60^{\mathrm{a}}$ & $394.19 \pm 34.20^{\mathrm{a}}$ & $390.53 \pm 21.02^{\mathrm{a}}$ \\
\hline
\end{tabular}

Data are represented as mean \pm SD. Values in the same rows sharing the same superscript letter are not significantly different $(\mathrm{P}>0.05)$.

\section{Haematological parameters}

The blood RBC, WBC, Hb, Hct, Monocyte, Lynphocyte and Neutrophil counts of different groups are shown in Table 3 . The hematocryte percentage, haemoglobin and RBC counts, indices significant interaction $(\mathrm{P}<0.05)$ among the treatments and control. In opposite there were no significant different between WBC, monocyte, Lymphocyte and Neutrophil that fed L. edodes mushroom extract on compared with the control group $(\mathrm{P}>0.05)$.

Table 3. Effects of dietary L. edodes mushroom (\% feed) on Hematological parameters of beluga juveniles for 8 week using a one-way ANOVA ( $\mathrm{n}=3$ tank per treatment group with 15 fish per tank)

\begin{tabular}{lccccc}
\hline Parameter & Control & $\mathbf{0 . 5 \%}$ & $\mathbf{1 \%}$ & $\mathbf{1 . 5 \%}$ & $\mathbf{2 \%}$ \\
\hline RBC $\left(10^{6} \mathrm{ml}^{-1)}\right.$ & $0.10 \pm 0.02^{\mathrm{c}}$ & $0.11 \pm 0.03^{\mathrm{c}}$ & $0.13 \pm 0.05^{\mathrm{ab}}$ & $0.15 \pm 0.04^{\mathrm{b}}$ & $0.18 \pm 0.05^{\mathrm{a}}$ \\
$\mathrm{WBC}\left(10^{3} \mathrm{ml}^{-1)}\right)$ & $10.8 \pm 0.9^{\mathrm{a}}$ & $10.20 \pm 1.8^{\mathrm{a}}$ & $11.4 \pm 1.3^{\mathrm{a}}$ & $11.7 \pm 0.3^{\mathrm{a}}$ & $11.43 \pm 1.7^{\mathrm{a}}$ \\
$\mathrm{Hb}\left(\mathrm{g} \mathrm{dl}^{-1}\right)$ & $3.9 \pm 0.42^{\mathrm{b}}$ & $4.7 \pm 0.58^{\mathrm{ab}}$ & $4.9 \pm 0.82^{\mathrm{ab}}$ & $5.1 \pm 0.63^{\mathrm{ab}}$ & $5.5 \pm 0.94^{\mathrm{a}}$ \\
Hct $(\%)$ & $33.2 \pm 1.12^{\mathrm{b}}$ & $35.2 \pm 1.4^{\mathrm{b}}$ & $36.1 \pm 1.7^{\mathrm{b}}$ & $35.9 \pm 0.9^{\mathrm{b}}$ & $39.1 \pm 1.2^{\mathrm{a}}$ \\
Monocyte $(\%)$ & $10.9 \pm 0.9^{\mathrm{a}}$ & $12.1 \pm 0.5^{\mathrm{a}}$ & $13.3 \pm 1.1^{\mathrm{a}}$ & $11.3 \pm 0.8^{\mathrm{a}}$ & $11.9 \pm 1.3^{\mathrm{a}}$ \\
Lymphocyte $(\%)$ & $63.1 \pm 1.2^{\mathrm{a}}$ & $62.2 \pm 3.3^{\mathrm{a}}$ & $64.2 \pm 1.4^{\mathrm{a}}$ & $65.2 \pm 2.4^{\mathrm{a}}$ & $67.1 \pm 2.11^{\mathrm{a}}$ \\
Neutrophil $(\%)$ & $21.4 \pm 2.12^{\mathrm{a}}$ & $19.8 \pm 1.8^{\mathrm{a}}$ & $20.3 \pm 3.5^{\mathrm{a}}$ & $20.7 \pm 1.5^{\mathrm{a}}$ & $22.1 \pm 3.5^{\mathrm{a}}$
\end{tabular}

Data are represented as mean \pm SE. Values of means in columns were significantly different $(P<0.05)$. 


\section{Innate immune parameters}

Innate immune responses of beluga juvenile fed on different levels of dietary $L$. edodes mushroom extract are shown in Table 4. There was a remarkable increase $(\mathrm{P}<0.05)$ in the lysozyme activity and SOD between treatment compare with the control group. But, in the same time (8 weeks), according to statistical analysis of data, there were no significant differences $(\mathrm{P}>0.05)$ of serum total immunoglobulin (Ig) and Alternative complement activity (ACH50). The highest Respiratory burst activity was observed in fish in control group and the lowest was observed in fish fed on $2 \%$ L. edodes mushroom extract.

Table 4. Effects of dietary L. edodes mushroom extract on Innate immune parameters of beluga juveniles for 8 weeks

\begin{tabular}{llllll}
\hline Parameter & Control & $\mathbf{0 . 5 \%}$ & $\mathbf{1 \%}$ & $\mathbf{1 . 5 \%}$ & $\mathbf{2 \%}$ \\
\hline lysozyme & $23.1 \pm 1.15^{\mathrm{b}}$ & $26.7 \pm 2.17^{\mathrm{b}}$ & $27.3 \pm 3.15^{\mathrm{b}}$ & $29.8 \pm 1.18^{\mathrm{b}}$ & $36.4 \pm 2.12^{\mathrm{a}}$ \\
SOD & $37.4 \pm 3.07^{\mathrm{b}}$ & $35.3 \pm 3.41^{\mathrm{b}}$ & $39.6 \pm 2.41^{\mathrm{b}}$ & $41.8 \pm 3.27^{\mathrm{b}}$ & $47.5 \pm 4.02^{\mathrm{a}}$ \\
Ig & $32.7 \pm 2.25^{\mathrm{a}}$ & $33.1 \pm 3.07^{\mathrm{a}}$ & $36.7 \pm 4.05^{\mathrm{ab}}$ & $37.8 \pm 2.31^{\mathrm{ab}}$ & $38.1 \pm 3.41^{\mathrm{ab}}$ \\
ACH50 & $140.4 \pm 14.24^{\mathrm{a}}$ & $145.3 \pm 12.52^{\mathrm{a}}$ & $142.6 \pm 13.35^{\mathrm{a}}$ & $151.8 \pm 14.08^{\mathrm{a}}$ & $148.5 \pm 13.52^{\mathrm{a}}$ \\
Respiratory burst & $1390.4 \pm 145.12^{\mathrm{a}}$ & $1421.8 \pm 121.41^{\mathrm{a}}$ & $1434.2 \pm 155.35^{\mathrm{ab}}$ & $1428.5 \pm 138.53^{\mathrm{ab}}$ & $1441.7 \pm 148.54^{\mathrm{ab}}$ \\
activity $($ OD630) & & &
\end{tabular}

\section{Discussion}

This essay was carried out, to find the effect of L. edodes mushroom extract which was added to the commercial feed as increment of growth performance, hematological levels, immune response and some biochemical parameters improved. According to the results of the study, feeding the beluga juvenile fish with $2 \% L$. edodes supplemented diet was significantly better than other treatments in growth performance, some biochemical, hematological and immunological parameters. In the present study, we found that feeding of fish with $2 \% \mathrm{~L}$. edodes significantly improved SGR and FCR $(\mathrm{P}<0.05)$ in beluga juvenile which means that the mushroom diet acted as an appetiser. The changes in growth and feed intake suggest that dietary mushroom may play a role in changing the enzyme activity related to digestion that consequently improves the feed digestibility and nutrient absorption. Alike to our results, research the improvement of growth performance and feed proficiency were reported in great sturgeon after feeding ginger (Zingiber officinale) (Vahedi et al. 2017) and nettle (Urtica dioica) (Binaii et al. 2014). Furthermore the beluga juvenile fed onion powder onion (Allium cepa) significantly showed higher growth performance compared with those of the control group (Akrami et al. 2015). Similarly Vahedi et al. (2017) observed that the supplementation of diet with ginger extract significantly increased beluga juvenile growth performance and Gholipour kanani et al. (2014) ) showed that the diet containing $Z$. 
officinale powder has increasingly affected the growth performance of beluga. From previous studies, it has been suggested that improvement growth performance might be due to chemical compounds such as lentinan, eritadenine, Lergotioneine (Bernaś et al. 2006) and several anti-oxidants (selenium,uric acid and vitamin A,C,E) as well as vitamin D (Mau et al. 2002) which found in mushroom. In agreement with result of our investigation the affects of any food supplemention added to the fish diet to improve its performance, will be different under the influance fish species, size, added dose, fish nutritional/physiological status, and/or milieu culturing conditions.

\section{hemato-biochemical parameters}

Haematological indices have been used in several studies to specify the nutritional and or pathological condition of an animal in response to various diets (Akpodiete \& Ologbodo 1998; Jahanbakhshi, Imanpoor, Taghizadeh, \& Shabani 2013), and are considered as indicators of animal health status. It is reported that all feed supplemented materials, couldn't have necessarily significant effects on hematological parameters including RBC, HB and PCV, and for assess their effective performance, it must consider performance time, concentration, method of administration and physiological condition of fish (Vahedi et al. 2017). Although use of herbal supplements have a positive effects on some hemato-biochemicals factors, but there is dependented to dose-diets, so that more or less than the optimum levels can have an inhibitory or unaffected effect (Awad, Austin, \& Lyndon 2013).
The present study revealed that the $\mathrm{RBC}$ of beluga received $2 \%$ mushroom extract was influenced positively during the experimental trial. Similar result was reported by Binaii et al. (2014), who obtained that there was remarkable enhancement in RBC for sturgeon fed diet nettle in comparison with the control. Unlike this investigation, the study on H. huso (Gholipour kanani et al. 2014; Akrami et al. 2015b) and Vahedi et al. (2017) demonstrated erythrocytes remained impressed after feeding pharmaceuticalherbs. These various results may have been caused by the discrepancy effects of medicinal plants or different immune system responses per fish.. In the current research, the haemogolobin content in the treated groups was remarkably upper than the control, which illustrates that oxygen supply increases consequently, reflecting beneficial health effect on fish. The result of this study is parallel with the finding of Binaii et al. (2014) who obtained $\mathrm{Hb}$ was affected in great sturgeon juvenile fed $12 \%$ nettle. Conversely, Gholipour kanani et al. (2014) and Akrami et al. (2015b) found that the level of $\mathrm{Hb}$ were not significantly effected by ginger and onion in the basal diet of juvenile beluga, respectively. According to the present study, the $\mathrm{Hct} \%$ in the blood of fish fed with $2 \%$ mushroom extract supplemented diets significantly increased in comparison with those fed the control diet and demonstrated the positive health properties on fish. Similar effect were observed in beluga fed diet supplementation with herbal plants (Binaii et al. 2014; Gholipour kanani et al. 2014; Akrami et al. 2015b). On the contrary, result obtained by Vahedi et al. (2017) showed that the 
supplement of ginger extract did not affect the amount Hct of sturgeon fish. Different effects of herbal plant and immune system reactions in distinct species of fish against these compounds can be attributed to these different results. In our study, the number of white blood cells and differential leukocyte counts (monocyte, lymphocyte and neutrophil) had not considerable change $(\mathrm{P}>0.05)$ between treatment groups with compared to the control group. White blood cells (WBC) are body defender against diseases and in case of infection in the body will be increased (Abdelmalek, Driss, Kallel, Guargouri, Missaoui, Chaabouni, Ayadi \& Bougatef. 2015). Compatible to our study Vahedi et al. (2017) were recorded these blood cells were not significantly affected by ginger extract in diet of $H$. huso. Our results coincides with the investigation of study which demonstrated that Zinger Supplement in eight weeks had no remarkable effect on white blood cell levels of great sturgeon (Gholipour kanani et al. 2014). On the other hand Binaii et al. (2014) and Akrami et al. (2015b) reported that the addition of nettle (Urtica dioica) and onion powder considerably increased the number of white blood cells in the beluga, respectively on the end of trial.

\section{Biochemistry}

Biochemical assessment is used as a health indicator in animals. Alteration of blood biochemical contents must have changed in physiological characteristics. The result of present study revealed that, there were no significant differences in glucose among treatments, although the goup tested with $2 \%$ mushroom extract had a lower glucose. The results of current study are parallel with finding of Binaii et al. (2014) and Vahedi et al. (2016) stated that glucose levels did not change with the use of diet containing nettle and ginger, respectively. These results are disagreement with the Akrami et al. (2015) results, who founded by onion supplementation that noted diminished glucose after feedings with onion powder diet in H. huso. According to some scholars, serum total proteins is recognized as the most important index of nutritional and the health status of fish (Patriche, Patriche \& Tenciu 2009). In our investigatin, total protein of juvenile great sturgron was not altetnation after feeding with different doses of mushroom extract at the end of the eight week which is in line with the prior work of Vahedi et al. 2017 who noted non-significant different in total protein. Netevertheless the use of ginger flour as supplemented diet could cause the enhancement of total protein in juvenile $H$. huso (Gholipour Kanani et al. 2014). Prior research by Binaii et al. (2014) have illustrated that supplementation with 12 percent $U$. dioica remarkably enhancement the total serum protein of great sturgeon, whrease use $1 \%$ of onion powder in the beluga diet effected remarkably reduced the total protein content compared to the control group. (Akrami et al. 2015b). The bioactive compounds found in mushroom directly affect human health by activating immune mechanism (Regula \& Siwulski, 2007). The bioactive compounds found in mushroom straightly affect human safty via activating immune mechanism. Total 
polyphenols were the major naturally occurring antioxidant ingredients found in the methanolic extracts and suggests a Cholesterol-lowering potential (Mau et al.2002). In the present study, cholestrol concentration was strongly affected by feeding sturgeon with mushroom extract. These results are agree with those of Akrami $e t$ al. (2015b) and Vahedi et al (2017) in beluga treated with onion and ginger, respectively (Akrami et al. 2015b; Vahedi et al. 2017). Moreover, mushroom extract did not remarkably affect on triglyceride and lipid in comparison with the control. However, the lowest value of triglyceride and lipid were observed in $2 \%$ mushroom extract treatment. The reduction of triglycerides could depend on saponin exist in fungus as described in (Lee, Lim, Kang, Min, Son, Lee, Park, Ngo, Tran, Lim \& Hwang 2012). Conversely, Akrami et al. (2015b) demonstrated that the use of $1 \%$ onion powder in beluga diet decreased the amount of triglyceride significantly in comparison with the control. Furthermore, Binaii et al. (2014) in their study, did not observed any change the level of cholesterol and triglyceride in their fourth week after consumption of nettle supplement, while in the eighth week, treatments fed $6 \%$ and $12 \%$ nettle in the diet remarkably decreased against other groups. AST, ALT, LDH and ALP enzymes are known as indexs ndices of liver damage (Bhardwaj, Srivastava, Kapoor \& Srivastava 2010). In this study AST, LDH of juvenile sturgeon were not influenced by different level of mushroom extract, wherease levels of ALT and ALP in the serum are affected remarkably. It seems that bioactive compounds polyphenols, flavonoids and saponins found in mushroom prevent lipid peroxidation of cell membranes and intercept the release of mentioned enzymes into the plasma (Bobek et al. 1991). Conversely this investigation, result was obtained by Akrami $e t$ al. (2015b) which reported that AST and LDH levels illustrated a considerable decrease in great surgeon juvenile fed diet with $1 \%$ onion in comparison with the control, while ALT and ALP levels were not impressed. Gholipour kanani et al. (2014) and Binaii et al. (2014) who revealed that there were no remarkably decreased ALT, ALP and AST in H. huso fed diet ginger and nettle in comparison with the control. The serum lysozyme activity is considered as a defense barrier against bacterial pathogens thus resulting in the reduction of disease (Misra \& Fridovich 1972). In current investigation, lysozyme activity of $H$. huso was also enhanced by increasing the concentration of the mushroom extract in the supplemented diets in comparison with the control group. The enhunced activity of lysozyme due to the role of mushroom extract supplemented diet in enhancing the non-specific immune response in great sturgeon. This result is consistence with earlier studies of (Baba, Uluköy \& Öntaş 2015) who reported that the feeding $2 \%$ mushroom extract increased lysozyme activity of Oncorhynchus mykiss. Also, elevated lysozyme activity have been reported in beluga after supplementing diets with $1 \%$ onion powder (Akrami et al. 2015b). However, On the contrary, this investigatin, lysozyme activity was not impressed in juvenile great sturgeon fed with ginger (Gholipour kanani et al. 2014). Superoxide dismutase (SOD) as an important 
anti-oxidation enzyme widely exists in tissues of aerobic and anaerobic organisms. In the current essay, fish fed diets supplemented with $2 \%$ L. edodes mushroom extract showed remarkably higher SOD activities when compared to the other experimental diet. The enhancement activity of SOD in the serum supported the role of mushroom extract supplemented diet in enhancing the nonspecific immune response in beluga. This result is in agreement with those obtained by Akrami et al. (2015b) who found that an enhancement in beluga SOD enzyme after feeding with onion powder. Conversely, Vahedi et al. (2017) found that there was an increase in the SOD activity in beluga treated with ginger extract. Moreover, Lv, Zhou, Rudeaux, \& Respondek (2007) reported that diet supplemented with herbal immune regulation mixture (HIRM) extract did not increase SOD activity of common carp (Cyprinus carpio).This possibly attributed to be that each pharmaceutic plant a particular district of the host immune system or that the time era for induction of immune response by medicine plant differs with respect to type of immune parameter. Immunoglobulins are one of the major molecules in humoral immunity of vertebrates. In our experiment, mushroom extract had no considerable on a serum total immunoglobulin in beluga fed diet in comparison with the control group. Baba et al. (2015) found that significant enhancement in serum total immunoglobulin of rainbow trout (O. mykiss) fed with $2 \%$ L. edodes mushroom extract supplemented diet. Prior studies have demonstrated a considerable individual variation in serum IgM levels between fish.
Some changes might be related to size (Magnadóttir et al. 1999a; Picchietti, Scapigliati, Fanelli Barbato, Canese, Mastrolla, Mazzini \& Abelli 2001) environmental conditions (Klesius, 1990; Magnadóttir et al. 1999b) or disease status (Magnadóttir et al. 1995; Nielsen 1999). Unlike this study, some researchers reported an enhancement of the IgM level after using medicine plants in $H$. huso (Binaii et al., 2014; Akrami et al. 2015b; Vahedi et al. 2017). The complement system is an vital and effective part of the innate immune system. The current study demonstrated that supplementation of diet with different levels of mushroom extract did not remarkably affect on complement activity (ACH50) in plasma great sturgeon juveniles. Conversely to this results enhancement in the total complement activity were reported in fish fed with a diet enriched with Pomegranate, Pyrethrum and Prickly ash extract (Harikrishnan et al. 2011), S. marianum (Ahmadi, Banaee, Vosoghei, Mirvaghefei \& Ataeimehr 2012) and Nasturium nasturtium extracts (Asadi, Mirvaghefei, Nematollahi, Banaee \& Ahmadi 2012). The manufactures of oxygen free radicals by neutrophils via the respiratory burst are momentous events in bactericidal pathways in fish (Sharp \& Secombes, 1993) the first product released from the respiratory burst is anion superoxide; hence, an accurate evaluation of this activity can be via $\mathrm{O}_{2}^{-}$measurement (Secombes, 1990). The results of the curret investigation demonstrated that there were no considerable differences in respiratory burst activity among treatment, although the group tested with $2 \%$ L. edodes mushroom extract had higher respiratory burst 
activity. This is in disagreement with the study of Binaii et al. (2014) and Akrami et al (2015b), which noticed greater respiratory burst activity in great sturgeon administred with dietary nettle and onion after feeding for 8 weeks.

Based on the results, it could be inferred that feeding beluga with $2 \% \quad L$. edodes mushroom extract improved growth performance and hemato-immunological indices.

\section{Conflict of interests}

The authors declare that there is no conflict of interests regarding the publication of this paper.

\section{Refrences}

Abtahi, B., Yousefi, M., \& Kenari, A. A. (2013). Influence of dietary nucleotides supplementation on growth, body composition and fatty acid profile of Beluga sturgeon juveniles (Huso huso). Aquaculture Research, 44(2), 254-260.

Ai, Q., Mai, K., Tan, B., Xu, W., Duan, Q., Ma, H., \& Zhang, L. (2006). Replacement of fish meal by meat and bone meal in diets for large yellow croaker, Pseudosciaena crocea. Aquaculture, 260(1-4), 255-263.

Akrami, R., Gharaei, A., Mansour, M. R., \& Galeshi, A. (2015). Effects of dietary onion (Allium cepa) powder on growth, innate immune response and hemato-biochemical parameters of beluga (Huso huso Linnaeus, 1754) juvenile. Fish \& shellfish immunology, $45(2), 828-834$.
Akrami, R., Iri, Y., Rostami, H. K., \& Mansour, M. R. (2013). Effect of dietary supplementation of fructooligosaccharide (FOS) on growth performance, survival, lactobacillus bacterial population and hemato-immunological parameters of stellate sturgeon (Acipenser stellatus) juvenile. Fish \& shellfish immunology, 35(4), 1235-1239.

Alberto, M., Rinsdahl, Canavosio, M., \& Manca de Nadra, M. (2006). Antimicrobial effect of polyphenols from herbs. Food Chem, 105, 940-949.

Amlashi, A. S., Falahatkar, B., Sattari, M., \& Gilani, M. T. (2011). Effect of dietary vitamin $\mathrm{E}$ on growth, muscle composition, hematological and immunological parameters of sub-yearling beluga Huso huso L. Fish \& shellfish immunology, 30(3), 807-814.

Asadi, F., Hallajian, A., Asadian, P., Shahriari, A., \& Pourkabir, M. (2009). Serum lipid, free fatty acid, and proteins in juvenile sturgeons: Acipenser persicus and Acipenser stellatus. Comparative Clinical Pathology, 18(3), 287289.

Austin, B., \& Austin, D. A. (1989). Methods for the microbiological examination of fish and shellfish: Halsted Press.

Abdelmalek, B.E., Driss, D., Kallel, F., Guargouri, M., Missaoui, H., Chaabouni, S.E., Ayadi, M.A. and Bougatef, A. (2015). Effect of xylan oligosaccharides generated from corncobs on food acceptability, growth performance, haematology and immunological 
parameters of Dicentrarchus labrax fingerlings.

Fish physiology and biochemistry, 41(6), 15871596.

Ahmadi, K., Banaee, M., Vosoghei, A., Mirvaghefei, A., \& Ataeimehr, B. (2012). Evaluation Of The Immunomodulatory Effects Of Silymarin Extract (Silybum Marianum) On Some Immune Parameters Of Rainbow Trout, Oncorhynchus mykiss (Actinopterygii: Salmoniformes: Salmonidae). Acta Ichthyologica Et Piscatoria, 42(2).

Akpodiete, O., \& Ologbodo, A. (1998). The nutrients value of maggot meal in broiler Chicks in nutrients retention, haematology and serum chemistry. In Proc. 3rd Annu. Conf. Anim. Sci. Assoc. Nig., Lagos (pp. 41-42).

Asadi, M., Mirvaghefei, A., Nematollahi, M., Banaee, M., \& Ahmadi, K. (2012). Effects of Watercress (Nasturtium nasturtium) extract on selected immunological parameters of rainbow trout (Oncorhynchus mykiss). Open Veterinary Journal, 2(1), 32-39.

Awad, E., Austin, D., \& Lyndon, A. (2013). Effect of black cumin seed oil (Nigella sativa) and nettle extract (Quercetin) on enhancement of immunity in rainbow trout, Oncorhynchus mykiss (Walbaum). Aquaculture, 388, 193197.

Baba, E., Uluköy, G., \& Öntaş , C. (2015). Effects of feed supplemented with Lentinula edodes mushroom extract on the immune response of rainbow trout, Oncorhynchus mykiss, and disease resistance against
Lactococcus garvieae. Aquaculture, 448, 476482.

Bhardwaj, S., Srivastava, M., Kapoor, U., \& Srivastava, L. (2010). A 90 days oral toxicity of imidacloprid in female rats: morphological, biochemical and histopathological evaluations. Food and chemical toxicology, 48(5), 11851190.

Bernaś, E., Jaworska, G., \& Lisiewska, Z. (2006). Edible mushrooms as a source of valuable nutritive constituents. Acta Scientiarum Polonorum Technologia Alimentaria, 5(1), 5-20.

Binaii, M., Ghiasi, M., Farabi, S.M.V., Pourgholam, R., Fazli, H., Safari, R., Alavi, S.E., Taghavi, M.J. and Bankehsaz, Z. (2014). Biochemical and hemato-immunological parameters in juvenile beluga (Huso huso) following the diet supplemented with nettle (Urtica dioica). Fish \& shellfish immunology, 36(1), 46-51.

Bobek, P., Ginter, E., Kuniak, L., Babala, J., Jurcovicova, M., Ozdin, L., \& Cerven, J. (1991). Effect of mushroom Pleurotus ostreatus and isolated fungal polysaccharide on serum and liver lipids in Syrian hamsters with hyperlipoproteinemia. Nutrition (Burbank, Los Angeles County, Calif.), 7(2), 105-108.

Borges, A., Scotti, L. V., Siqueira, D. R., Jurinitz, D. F., \& Wassermann, G. F. (2004). Hematologic and serum biochemical values for jundiá (Rhamdia quelen). Fish physiology and biochemistry, 30(1), 21-25. 
Chang, S., \& Miles, P. (2011). Recent trends in world production of cultivated edible mushrooms. Mushroom Journal, 504, 15-17.

Ghiasi, F., Mirzargar, S., Badakhshan, H., \& Shamsi, S. (2010). Effects of low concentration of cadmium on the level of lysozyme in serum, leukocyte count and phagocytic index in Cyprinus carpio under the wintering conditions. Journal of fisheries and Aquatic Science, 5(2), 113-119.

Gholipour Kanani, H., Nobahar, Z., Kakoolaki, S., \& Jafarian, H. (2014). Effect of ginger-and garlic-supplemented diet on growth performance, some hematological parameters and immune responses in juvenile Huso huso. Fish physiology and biochemistry, 40(2), 481-490.

Hevrøy, E., Espe, M., Waagbø, R., Sandnes, K., Ruud, M., \& HEMRE, G. I. (2005). Nutrient utilization in Atlantic salmon (Salmo salar L.) fed increased levels of fish protein hydrolysate during a period of fast growth. Aquaculture Nutrition, 11(4), 301-313.

Harikrishnan, R., Balasundaram, C., \& Heo, M. (2011). Impact of plant products on innate and adaptive immune system of cultured finfish and shellfish. Aquaculture, 317(1-4), 1-15.

Jalali, M. A., Hosseini, S. A., \& Imanpour, M. R. (2008). Effect of vitamin E and highly unsaturated fatty acid-enriched Artemia urmiana on growth performance, survival and stress resistance of Beluga (Huso huso) larvae. Aquaculture Research, 39(12), 1286-1291.
Jahanbakhshi, A., Imanpoor, M., Taghizadeh, V., \& Shabani, A. (2013). Jahanbakhshi, A., Imanpoor, M. R., TaghizadeHematological and serum biochemical indices changes induced by replacing fish meal with plant protein (sesame oil cake and corn gluten) in the Great sturgeon (Huso huso). Comparative Clinical Pathology, 22(6), 1087-1092.

Klesius, P. (1990). Effect of size and temperature on the quantity of immunoglobulin in channel catfish, Ictalurus punctatus. Veterinary Immunology and Immunopathology, 24, 187-195.

Lee, J., Lim, S., Kang, S.M., Min, S., Son, K., Lee, H.S., Park, E.M., Ngo, H.T., Tran, H.T., Lim, Y.S. and Hwang, S.B. (2012). Saponin inhibits hepatitis $\mathrm{C}$ virus propagation by upregulating suppressor of cytokine signaling 2 . PloS one, 7(6), e39366.

Lv, H., Zhou, Z., Rudeaux, F., \& Respondek, F. (2007). Effects of dietary short chain fructooligosaccharides on intestinal microflora, mortality and growth performance of Oreochromis aureus $\hat{\sigma} \times \mathrm{O}$. niloticus + . Chinese Journal of Animal Nutrition, 19(6), 691-697.

Mansour, M. R., Akrami, R., Ghobadi, S., Denji, K. A., Ezatrahimi, N., \& Gharaei, A. (2012). Effect of dietary mannan oligosaccharide (MOS) on growth performance, survival, body composition, and some hematological parameters in giant sturgeon juvenile (Huso huso Linnaeus, 1754). Fish physiology and biochemistry, 38(3), 829-835. 
Maqsood, S., Samoon, M., \& Singh, P. (2009). Immunomodulatory and growth promoting effect of dietary levamisole in Cyprinus carpio fingerlings against the challenge of Aeromonas hydrophila. Turkish Journal of Fisheries and Aquatic Sciences, 9(1).

Mariappan, S., Vinayagam, S., \& Durai, M. (2015). Phytochemical screening of bioactive compounds from Pleurotus ostreatus (jacq.fr) kumm-an wild edible mushroom. World Journal of Pharmaceutical Research, 4(5), 1603-1618.

Martins, M., Tavares-Dias, M., Fujimoto, R., Onaka, E., \& Nomura, D. (2004). Haematological alterations of Leporinus macrocephalus (Osteichtyes: Anostomidae) naturally infected by Goezia leporini (Nematoda: Anisakidae) in fish pond. Arquivo Brasileiro de Medicina Veterinária $e$ Zootecnia, 56(5), 640-646.

Mau, J. L., Lin, H. C., \& Song, S. F. (2002). Antioxidant properties of several specialty mushrooms. Food Research International, $35(6), 519-526$.

Misra, H. P., \& Fridovich, I. (1972). The univalent reduction of oxygen by reduced flavins and quinones. Journal of Biological Chemistry, 247(1), 188-192.

Mohseni, M., Ozorio, R., Pourkazemi, M., \& Bai, S. (2008). Effects of dietary 1-carnitine supplements on growth and body composition in beluga sturgeon (Huso huso) juveniles. Journal of Applied Ichthyology 24(6), 646-649.
Magnadóttir, B., Gudmundsdóttir, S., \& Gudmundsdot, B. (1995). Study of the humoral response of Atlantic salmon (Salmo salar L.), naturally infected with Aeromonas salmonicida ssp. achromogenes. Veterinary immunology and immunopathology(1-2), 127-142.

Magnadóttir, B., Jónsdóttir, H., Helgason, S., Björnsson, B., Jørgensen, T., \& Pilström, L. (1999b). Humoral immune parameters in Atlantic cod (Gadus morhua L.): I. The effects of environmental temperature. Comparative Biochemistry and Physiology Part B: Biochemistry and Molecular Biology, 122, 173-180.

Magnadóttir, B., Jónsdóttir, H., Helgason, S., Björnsson, B., Jørgensen, T., \& Pilström, L. (1999a). Humoral immune parameters in Atlantic cod (Gadus morhua L.): II. The effects of size and gender under different environmental conditions. Comparative Biochemistry and Physiology Part B: Biochemistry and Molecular Biology, 122(2), 181-188.

Nielsen, M. (1999). An enhanced humoral immune response against the swim bladder nematode (Anguillicola crassus), in the Japanese eel (Anguilla japonica), compared with the European eel (A. anguilla). Journal of Helminthology, 73, 227-232.

Nijveldt, R. J., Van Nood, E., Van Hoorn, D. E., Boelens, P. G., Van Norren, K., \& Van Leeuwen, P. A. (2001). Flavonoids: a review of probable mechanisms of action and potential applications. The American journal of clinical nutrition, 74(4), 418-425. 
Ortuño, J., Cuesta, A., Rodríguez, A., Esteban, M. A., \& Meseguer, J. (2002). Oral administration of yeast, Saccharomyces cerevisiae, enhances the cellular innate immune response of gilthead seabream (Sparus aurata L.). Veterinary immunology and immunopathology, 85(1-2), 41-50.

Patriche, T., Patriche, N., \& Tenciu, M. (2009). Cyprinids total blood proteins determination.

Scientific Papers Animal Science and Biotechnologies, 42(2), 95-101.

Picchitti, S., Scapigliati, G., Fanelli, M., Barbato, F., Canese, S., Mastrolla, L., Mazzini, M. and Abelli, L. (2001). Sex-related variations of serum immunoglobulins during reproduction in gilthead sea bream and evidence for a transfer from the female to the eggs. Journal of Fish Biology, 59, 1503-1511.

Recio, M., Rios, J., \& Villar, A. (1989). Antimicrobial activity of selected plants employed in the Spanish Mediterranean area. Part II. Phytotherapy research, 3(3), 77-80.

Reguła, J., \& Siwulski, M. (2007). Dried shiitake (Lentinulla edodes) and oyster (Pleurotus ostreatus) mushrooms as a good source of nutrient. Acta Scientiarum Polonorum Technologia Alimentaria, 6(4), 135-142.

Schaperclaus,W., Kulow, H., Schreckenbach, K. (1991) Hematological and serological technique. In: Kothekar, V.S. (Ed.), Fish Disease, 2nd ed. Oxonian Press, New Delhi, pp. $71-108$.
Sheikhzadeh, N., Nofouzi, K., Delazar, A., \& Oushani, A. K. (2011). Immunomodulatory effects of decaffeinated green tea (Camellia sinensis) on the immune system of rainbow trout (Oncorhynchus mykiss). Fish \& shellfish immunology, 31(6), 1268-1269.

Sinha, A. K. (1972). Colorimetric assay of catalase. Analytical biochemistry, 47(2), 389394.

Smith, J., Rowan, N., \& Sullivan, R. (2002). Medicinal mushrooms: their therapeutic properties and current medical usage with special emphasis on cancer treatments. Univ. Strathclyde, Glasgow, UK.: Cancer Research UK London.

Soleimani, N., Hoseinifar, S. H., Merrifield, D. L., Barati, M., \& Abadi, Z. H. (2012). Dietary supplementation of fructooligosaccharide (FOS) improves the innate immune response, stress resistance, digestive enzyme activities and growth performance of Caspian roach (Rutilus rutilus) fry. Fish \& shellfish immunology, 32(2), 316-321.

Stasiack, A., \& Bauman, C. (1996). Neutrophil activity as a potent indicator for concomitant analysis. Fish Shellfish Immunology, 37, 539.

Secombes, C. (1990). Isolation of salmonid macrophages and analysis of their killing activity. Techniques in fish immunology, 137-154.

Sharp, G., \& Secombes, C. (1993). The role of reactive oxygen species in the killing of the bacterial fish pathogen Aeromonas salmonicida 
by rainbow trout macrophages. Fish \& Shellfish Immunology, 3(2), 119-129.

Siwicki, A., \& Anderson, D. (1993). Nonspecific defense mechanisms assay in fish. II. Potential killing activity of neutrophils and macrophages, lysozyme activity in serum and organs and total immunoglobulin (Ig) level in serum. Olsztyn, Poland: Fish diseases diagnosis and preventions methods, 105-12. Olsztyn, Poland.

Tacon, A.G.J. (1990) Standard Methods for the Nutrition and Feeding of Famed Fish and Shrimp, pp. 424. Argent Laboratories Press, Redmond, WA, USA.

Thoppil, R. J., \& Bishayee, A. (2011). Terpenoids as potential chemopreventive and therapeutic agents in liver cancer. World journal journal of hepatology, 3(9), 228.
Vahedi, A., Hasanpour, M., Akrami, R., \& Chitsaz, H. (2017). Effect of dietary supplementation with ginger (Zingiber officinale) extract on growth, biochemical and hemato-immunological parameters in juvenile beluga (Huso huso). Iranian Journal of Aquatic Animal Health, 3(1), 26-46.

Wandati, T., Kenji, G., \& Onguso, J. (2013). Phytochemicals in edible wild mushrooms from selected areas in Kenya. Journal of Food Research, 2(3), 137.

Yap, A.T., \& Ng, M.L. (2001). An improved method for the isolation of lentinan from the edible and medicinal shiitake mushroom, Lentinus edodes (Berk.) Sing. (Agaricomycetideae). International Journal of medicinal mushrooms, 3(1). 
تأثير عصاره قارج (Lentinula edodes) بر عملكرد رشد، ياسخ ايمنى و فراسنجههاى خونى - بيوشيميايى در فيل ماهى جوان (Huso huso Linnaeus 1754) حسين جيت ساز”، رضا اكرمى و زيد احمدى كروه شيلات، واحد آزادشهر، دانشكاه آزاد اسلامى، آزادشهر، ايران

هدف از اين مطالعه، بررسى اثرات رزيم غذايى حاوى مكمل عصاره قارج (Lentinula edodes) بر عملكرد رشد و نرخ بقاء،

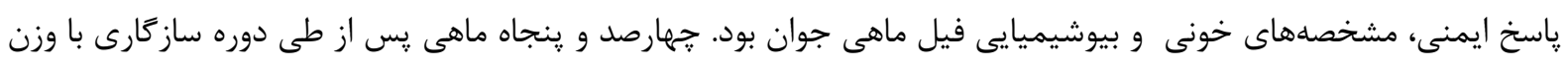

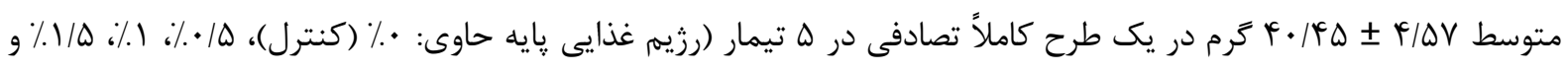

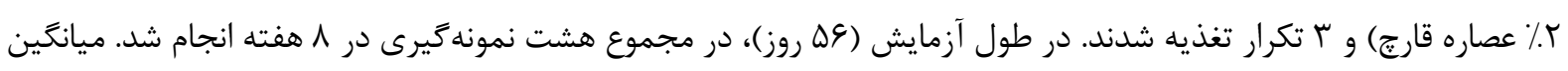

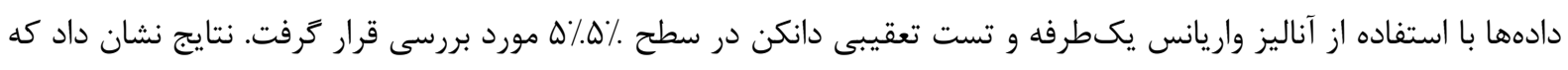

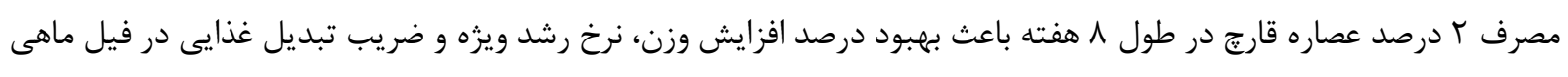

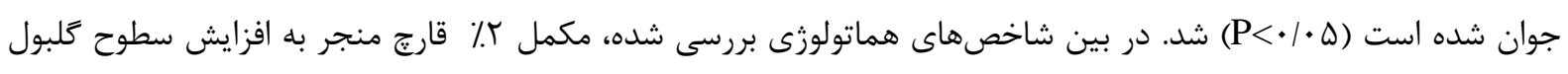

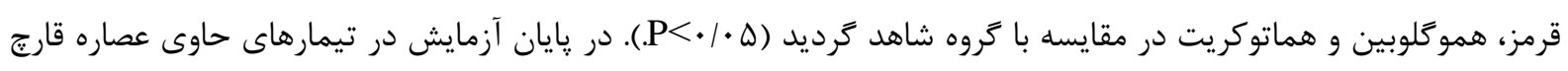

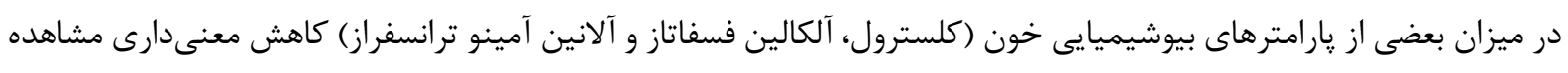

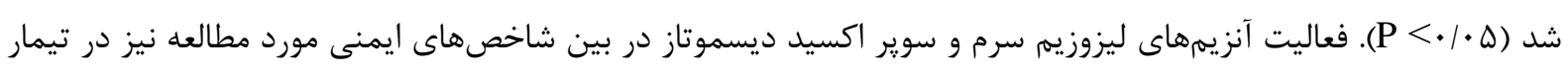

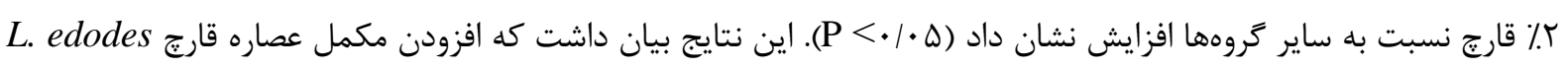

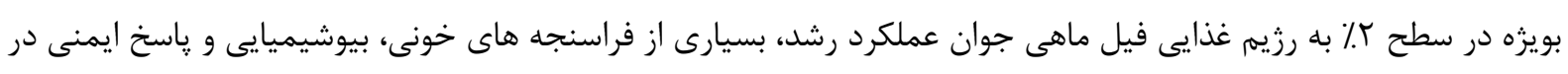
ماهى مذكور را بهبود بخشيد. كلمات كليدى: هماتو - ايمونولوزيكال، رشد، فيل ماهى، عصاره قارج. chitsaz2@gmail.com :نويسنده مسئول: 